\title{
Sources of organic matter affect depth-related microbial community composition in sediments of Lake Erhai, Southwest China
}

\author{
Wei XIONG, ${ }^{1}$ Ping XIE,${ }^{2 *}$ Shengrui WANG, ${ }^{3 *}$ Yuan NIU, ${ }^{3}$ Xi YANG,,${ }^{2}$ Wenjie $\mathrm{CHEN}^{1}$
}

${ }^{1}$ College of Fisheries, Huazhong Agricultural University, 430070 Wuhan; ${ }^{2}$ Donghu Experimental Station of Lake Ecosystems, State Key Laboratory of Freshwater Ecology and Biotechnology of China, Institute of Hydrobiology, Chinese Academy of Sciences, 430072 Wuhan; ${ }^{3}$ State Environmental Protection Key Laboratory for Lake Pollution Control, Research Center of Lake Eco-environment, Chinese Research Academy of Environmental Sciences, 100012 Beijing, China

*Corresponding author: xieping@ihb.ac.cn, shengruiwang@sohu.com

\begin{abstract}
Sediment cores taken from different areas of the mesotrophic Lake Erhai were analysed to investigate the vertical distribution of bacterial community composition (BCC), as well as physicochemical parameters. PCR-denaturing gradient gel electrophoresis (DGGE), stable carbon isotope $\left(\delta^{13} C\right), C / N$ atomic ratio and canonical correspondence analysis $(C C A)$ were used to explore the relationships between the succession of bacterial communities and environmental variables, emphasising changes in the sources of organic matter (OM). The BCC in natural environments was characterised by DGGE of the $16 \mathrm{~S}$ rRNA gene with subsequent sequencing of bands of interest. The $C C A$ revealed that the depth-related variation in sediment bacterial communities in different areas of the lake was significantly influenced by varying environmental factors. The OM source, however, played an important role in structuring BCC at all sites. The DGGE banding patterns revealed that the abundance of Deltaproteobacteria decreased with accompanying elevated levels of C4 plant-derived organic carbon. The sequencing of DGGE bands suggested that the majority of the sequences were affiliated with common phylogenetic groups in lake sediments: Chloroflexi, Deltaproteobacteria and Firmicutes. Betaproteobacteria detected in our study appeared as a prominent phylotype in the upper sediment. The Shannon-Wiener diversity index of bacterial communities was directly affected by the OM source. Constant OM sources resulted in a stable higher diversity of bacterial communities and broader enzymatic capabilities to access OM. We conclude that the differences in the diversity of bacterial communities in sediments differing in their sources of OM were related to environmental variables (e.g. water level, river runoff and terrestrial vegetation composition). Our study provided insights into the relationships between natural BCC and OM sources, facilitating a better understanding of microbial community structure in lake sediment.
\end{abstract}

Key words: Bacterial community composition, organic matter, denaturing gradient gel electrophoresis, $\delta^{13} C$, canonical correspondence analysis, sediment.

Received: September 2014. Accepted: October 2014.

\section{INTRODUCTION}

Sediments are one of the most diverse microbial habitats with distinct redox gradients (Torsvik et al., 2002) and represent an open system where physicochemical and biochemical reactions occur. Sediment microorganisms play a key role in the interchange of energy and matter between sediment and the water (Tong et al., 2005), such as the ability to regulate the carbon cycle and to degrade a broad range of organic matter $(\mathrm{OM})$ sources in aquatic systems (Kao and Prosser, 1999; Kao et al., 2001). The vertical sequence of electron acceptors roughly follows the decreasing efficiency of energy metabolisms in undisturbed sediments, and the depth-related gradient of biogeochemical properties provides a niche for metabolically diverse microorganisms (Koizumi et al., 2003). However, only few studies have investigated vertical changes of microbial communities in freshwater sediments and their $\mathrm{OM}$ sources. Primary production by phytoplankton, terrestrial plants, river runoff, municipal sewage and industrial dis- charge, etc., contribute to various sources of OM in sediments (Hedges and Keil, 1995; Hedges et al., 1997). The $\delta^{13} \mathrm{C}$ signatures of the various carbon sources are often different and serve as powerful tracers of carbon inputs in various environments, although some overlap occurs between different sources (Fry and Sherr, 1989; Meyers, 1994; Prahl et al., 1994; Schelske and Hodell, 1995). The sources of OM, nutrient status and pollution may influence the microbial community structure (Bååth et al., 1995; Pennanen, 2001). Traditional techniques of isolation and culturing have not been adequate for the characterisation of microorganisms in environmental samples, particularly in evaluating the natural microbial diversity (Fang et al., 2000; Delong and Pace, 2001). In recent years, molecular methods based on 16S rRNA, such as PCR-denaturing gradient gel electrophoresis (DGGE), terminal restriction fragment length polymorphism (T-RFLP), cloning and sequencing have been widely used to reveal intrinsic genetic diversity (Salles et al., 2002). PCR-DGGE fingerprinting has been widely used in environmental microbiology and 
has been available to detect the similarities and differences of the dominant populations of microbial communities (Muyzer and Smalla, 1998; Lindstrom, 2000; Dorigo et al., 2005). Although a few studies have focused on assessing microbial distribution in sediments and their function (Macalady et al., 2000; Zhao et al., 2008), data on the relationships between the vertical variation of bacterial community composition (BCC) and OM sources recorded in the sediments are still scarce.

This study represents the first attempt to investigate vertical gradients of natural microbial communities and environmental variables in Lake Erhai sediments. We especially focus on the relationship between BCC and OM sources represented by $\mathrm{C} / \mathrm{N}$ ratios and $\delta^{13} \mathrm{C}$ signatures. The two main objectives of our study are as follows: i) to describe the natural microbial community structure prole in sediment; and ii) to investigate the vertical gradients of environmental variables, particularly the content and sources of $\mathrm{OM}$ and their effects on natural microbial community structure. These may facilitate the understanding of relationships between natural microbial communities and environmental variables in plateau mesotrophic lake sediment.

\section{METHODS}

\section{Study site and sampling}

Sediment samples were collected at different locations and different depths from Lake Erhai, a mesotrophic plateau lake located in Dali, Yunnan province and the largest fault lake in southwest China (surface area: 249.8 $\mathrm{km}^{2}$, mean depth: $10.5 \mathrm{~m}$ ). Lake Erhai sits within an intermountain basin, there are high mountains stand up 2800 3500 $\mathrm{m}$ asl from the west and north of the lake, about 18 rivers and streams flow into the lake (Xu and Zheng, 2003). There is only one outlet (to the west in the southwest corner of the lake). Precipitation also influenced terrestrial runoff that supplied $\mathrm{C}$ from land to lake. The mean total phytoplankton biomass (in terms of $\mathrm{Chl}$ a) ranged from 5.5 $\mu \mathrm{g} / \mathrm{L}(\mathrm{Feb})$ to $31.5 \mu \mathrm{g} / \mathrm{L}$ (Sep) in Lake Erhai (Li E. et al., 2011). On the fluvial plain and lakeshore areas the vegetation is exclusively agricultural, with extensive irrigated areas supporting a double-cropping system of corn, rice, wheat, legumes and other vegetables (Dearing et al., 2008). The lake plays an important role in the local socio-economic activities (Guo et al., 2001; Wu et al., 2001). In recent years, water quality deterioration associated with rapid socio-economic development in the Lake Erhai Basin has acquired increasing attention from the public and the government (Guo et al., 2011).

Sediment cores (length: $50 \mathrm{~cm}$, diameter: $9 \mathrm{~cm}$ ) were collected from three sites (EH-1, EH-2 and EH-3) (Fig. 1) on 18 July 2010. The first sampling station (EH-1) was located in Hongshan Bay at a water depth of $11.2 \mathrm{~m}$. Hongshan Bay, an area without plants, is located in the northern end of Lake Erhai. It is located at the lower edge of the alluvial fan of the Yongan River, an inflow river. This area has an influx of OM pollution through non-point source agricultural run-off (Guo et al., 2001; Yang and Song, 2006). The second sampling station (EH-2), which was chosen because of its depth and lack of aquatic macrophytes, was located at the deepest point of the central lake body at a depth of $21 \mathrm{~m}$. This zone is under the intersection interface of the northern part of the lake and south lake current. The third sampling station (EH-3) was located in a flat-bottom site that is $8.3 \mathrm{~m}$ deep in the southern part of the lake, which was characterised by the presence of submersed macrophyte communities prior to 2000. The submersed macrophyte communities in these zones gradually disappeared during the 2003-2006 time period due to rising water levels.

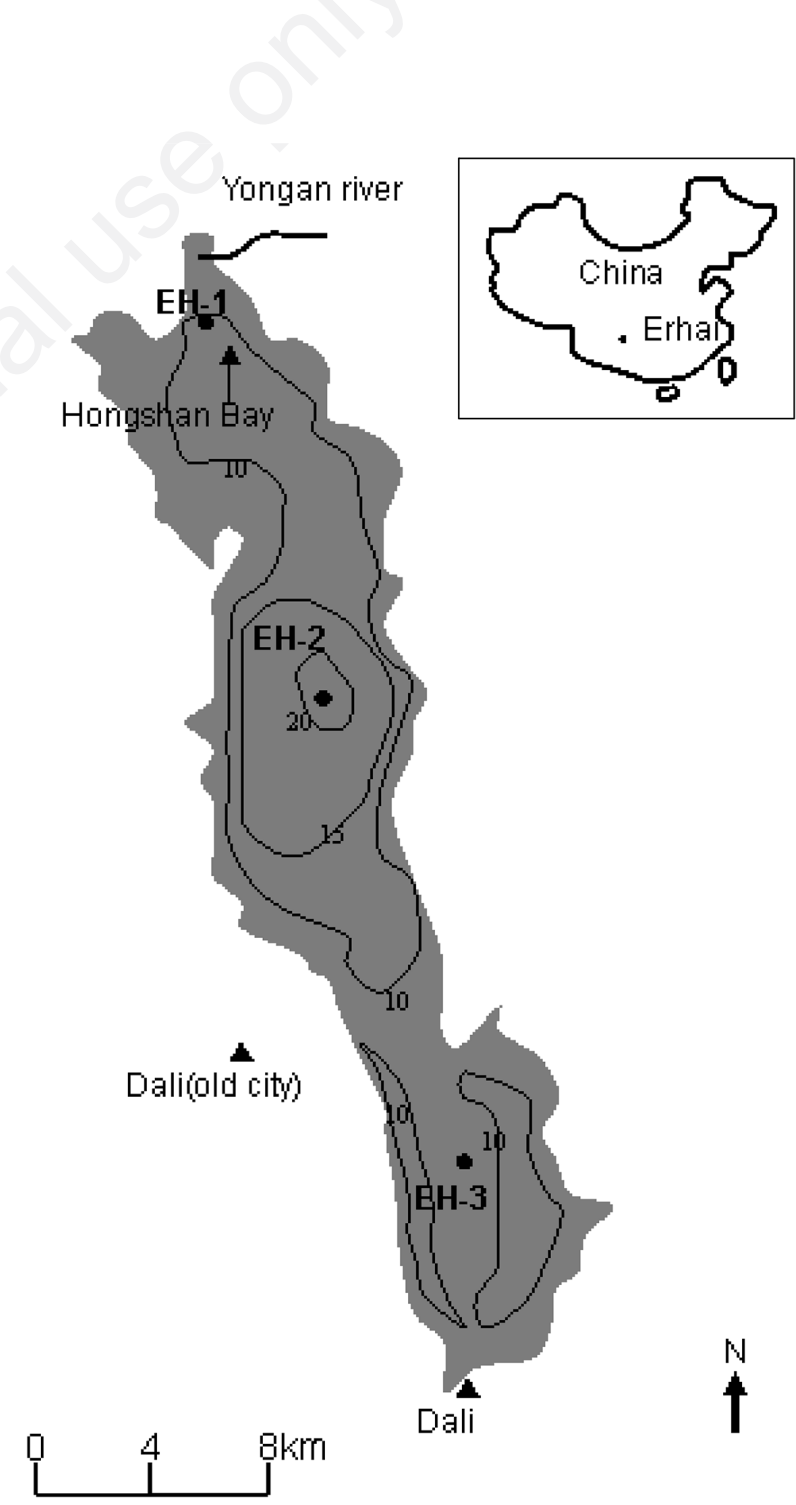

Fig. 1. Locations of the three sampling sites (EH-1, EH-2 and EH-3) in Lake Erhai. 
Sediment cores were collected with a core sampler (HL-CN, Hengling Technology Ltd. Corp., China). The cores were sectioned in 2-cm intervals between depths of $2 \mathrm{~cm}$ and $12 \mathrm{~cm}$, in 4-cm intervals between depths of 12 $\mathrm{cm}$ and $20 \mathrm{~cm}$ depth, and in 6-cm intervals between depths of $20 \mathrm{~cm}$ and $44 \mathrm{~cm}$. Three replicate cores were taken by the same sampling procedure. $\mathrm{pH}$ and oxidationreduction potential (Eh) were measured at each location. To minimize the risk of contamination, the samples were transferred to the laboratory in the dark at $4^{\circ} \mathrm{C}$ within 12 $\mathrm{h}$ in sterile plastic container by using alcohol-sterilized spatulas, the samples surfaces exposed to the air were discarded when processed. One portion of each sample was freeze dried, homogenized using agate mortar and pestle to a ne powder, then, used for physical and chemical analysis, and a second portion was frozen at $-80^{\circ} \mathrm{C}$ and used for DNA extraction. DNA extractions were conducted under sterile condition.

\section{Chemical analysis}

The potential of hydrogen $(\mathrm{pH})$ and the oxidation-reduction potential (Eh) were both measured with an ORP meter ( $\mathrm{pH} /$ ion meter 225, Iwaki Glass, Tokyo, Japan). Total nitrogen concentrations (TN), total phosphorus concentrations (TP) and total organic carbon content (TOC) were measured according to Jin and $\mathrm{Tu}$ (1990) after the sediment samples were dried with a Freeze Dryer (labconco, Cole-Parmer Instrument Co., Vernon Hills, IL, USA). For TOC determination, about $0.5 \mathrm{~g}$ sediment was mixed into $10 \mathrm{~mL}$ potassium dichromate buffer solution $(1 / 6 \times 0.400 \mathrm{~mol})$. The resulting slurry was then heated at $175^{\circ} \mathrm{C}$ for $10 \mathrm{~min}$, followed by addition of $5 \mathrm{~mL}$ phosphoric acid buffer (acid: $\left.\mathrm{H}_{2} \mathrm{O}=1: 1\right)$. Titration was performed using $0.2 \mathrm{~mol}$ ferrisulfas solution with sodium diphenylamine sulfonate as an indicator. The TOC:TN ratios $(\mathrm{C} / \mathrm{N})$ for sediments were determined using an elemental analyser (VarioEL, Elementar, Hanau, Germany). Subsamples of sediment for $\delta^{13} \mathrm{C}$ contents were acidified with $\mathrm{HCI}(1 \mathrm{~N})$ to remove carbonates. Traces of HCI were removed by washing the sediments several times with distilled water. The sediments were then used for bulk $\delta^{13} \mathrm{C}$ analysis. Values of $\delta^{13} \mathrm{C}$ were determined using an isotope ratio mass spectrometer (Delta V Advantage, Finnigan MAT, Bremen, Germany). The overall analytical precision for replicate samples was within $\pm 0.5 \%$. The analysis of ${ }^{13} \mathrm{C} /{ }^{12} \mathrm{C}$ was cross-referenced with the international Pee Dee Belemnite (PDB) standards and international cellulose samples $\operatorname{IAEA}_{2} \mathrm{C} 3\left(\delta^{13} \mathrm{C}=-24.91 \%\right)$ as a standard. The formula used for stable carbon isotope calculation was as follows:

$$
\delta^{13} \mathrm{C}(\% \mathrm{o})=\left(\mathrm{R}_{\text {sample }} / \mathrm{R}_{\text {standard }}-1\right) \times 1000
$$

where $R$ is the value of ${ }^{13} \mathrm{C} /{ }^{12} \mathrm{C}$.
The age-depth relationship in this study has been estimated using ${ }^{137} \mathrm{Cs}$ and ${ }^{210} \mathrm{~Pb}$ dating (Wan, 1999; $\mathrm{Xu}$ et al., 1999). ${ }^{210} \mathrm{~Pb}$ activity for ${ }^{210} \mathrm{~Pb}_{\mathrm{ex}}$ sedimentary dating was determined using $\alpha$-spectroscopy. ${ }^{137} \mathrm{Cs}$ activity was determined using a Canberra (Meriden, CT, USA), S-100 Multi-channel Analyzer.

\section{DNA extraction and PCR amplification}

The subsamples of sediments belonging to the same depth from each replicate were pooled for DNA extraction. Genomic DNA was extracted from $500 \mathrm{mg}$ of sediment from each depth using a Soil DNA kit (Omega Bio-Tek, Norcross, GA, USA) following the protocol of the manufacturer. The extracted DNA was used as template to amplify the $16 \mathrm{~S}$ rRNA gene fragment with the forward primer $341 \mathrm{f}$ (5'-CCTACGGGAGGCAGCAG-3') with a GC clamp (5'-CGCCCGCCGCGCGCGGCGGGCGGGGCGGGGG CACGGGGGC-3'); 907r (5'-CCGTCAATTCCTTTGAGTTT-3') was used as the reverse primer (Teske et al., 1996). These primers were capable of amplifying most bacteria from the sediment samples. PCR mixtures $(50 \mu \mathrm{L})$ contained $1 \times$ PCR buffer, $1.5 \mathrm{mM} \mathrm{MgCl}_{2}, 200 \mathrm{mM}$ each dNTP, $0.2 \mathrm{mM}$ each primer, $2.5 \mathrm{U}$ of Taq DNA polymerase (Takara, Shiga, Japan), and $20 \mathrm{ng}$ of template DNA. A 5-min initial denaturation at $94^{\circ} \mathrm{C}$ was followed by a thermal cycling program as follows: 20 cycles of denaturation $\left(1 \mathrm{~min}\right.$ at $94^{\circ} \mathrm{C}$ ), annealing (1 min at an initial temperature of $65^{\circ} \mathrm{C}$, decreasing $0.5^{\circ} \mathrm{C}$ every cycle till a final temperature of $55^{\circ} \mathrm{C}$ ), and extension $\left(3 \mathrm{~min}\right.$ at $\left.72^{\circ} \mathrm{C}\right) ; 10$ cycles of denaturation $(1 \mathrm{~min}$ at $94^{\circ} \mathrm{C}$ ), annealing $\left(1 \mathrm{~min}\right.$ at $\left.55^{\circ} \mathrm{C}\right)$, and extension $(3 \mathrm{~min}$ at $72^{\circ} \mathrm{C}$ ), followed by a final 8 -min extension at $72^{\circ} \mathrm{C}$. A negative control, in which the template was replaced by an equivalent volume of sterile deionized water, was included. PCR products were confirmed by $1.5 \%$ agarose gel electrophoresis.

\section{Denaturating gradient gel electrophoresis}

A total of $600 \mathrm{ng}$ of PCR product for each sample was loaded onto a $6 \%(\mathrm{w} / \mathrm{v})$ polyacrylamide gel (37.5:1 acrylamide:bisacrylamide) with a denaturing gradient that ranged from $45 \%$ to $60 \%$, where $100 \%$ denaturant is dened as $7 \mathrm{M}$ urea and $40 \%$ deionized formamide. The denaturating gradient gel electrophoresis (DGGE) was performed with a Dcode system (Bio-Rad Laboratories, Philadelphia, PA, USA) using $1 \times$ TAE running buffer (20 $\mathrm{mM}$ Tris, $10 \mathrm{mM}$ acetic acid, $0.5 \mathrm{mM}$ EDTA, $\mathrm{pH} 8.0$ ) at $60^{\circ} \mathrm{C}$ for $11 \mathrm{~h}$ at $100 \mathrm{~V}$. The gel was stained with GelRed (Biotium, Hayward, CA, USA) nucleic acid staining solution (diluted 1:10,000) for $30 \mathrm{~min}$ and photographed using Gene Com. (Bio Image Systems, Inc., Jackson, MI, USA) under UV light. DGGE were performed separately for the three sites. 


\section{Sequencing and phylogenetic analyses of DGGE bands}

All visible DGGE bands were excised with a sterile razor blade and eluted overnight at $4^{\circ} \mathrm{C}$ in $40 \mu \mathrm{L}$ MilliQ water. A volume of $3 \mu \mathrm{L}$ of the supernatant was used as a template for reamplification with the same primer set as described above (without a GC clamp). The amplicons were electrophoresed again on a DGGE gel to check the position of the original band and then purified with a Gel Recovery Purification Kit (AxyPrepTM) and ligated into pMD18-T plasmid vector (Takara, Japan) following the manufacturer's instructions. The ligated DNA was transformed into Escherichia coli DH5a-competent cells. The recombinant clones were selected and then submitted for sequencing using M13 primers and an automated $\mathrm{ABI}$ sequencer at the Genomics Company (Wuhan, China). The $16 S$ rRNA gene sequences have been deposited to GenBank under the Accession No. KC788751 to KC788807.

CLUSTAL W program (Thompson et al., 1994) and the phylogenetic analyses were performed with the MEGA4.0 (Tamura et al., 2007) software package using neighbour-joining methods (Saitou and Nei, 1987). The sequences with similarities greater than $97 \%$ were grouped in one operational taxonomic unit (OTU).

\section{Cluster analysis of DGGE proles and statistical analysis}

Cluster analyses of DGGE proles were performed with the NTSYS program ver. 2.10e (Exeter software, Setauket, NY, USA). A binary matrix was constructed by scoring the presence or absence of DGGE bands. Pairwise similarities between gel banding patterns were quantified using the Dice coefficient as: $S_{D}=\left(2 N_{A B}\right) /\left(N_{A}+N_{B}\right)$, where $\mathrm{N}_{\mathrm{AB}}$ is the number of bands common to the samples $A$ and $\mathrm{B}$, and $\mathrm{N}_{\mathrm{A}}$ and $\mathrm{N}_{\mathrm{B}}$ are the number of bands in samples $\mathrm{A}$ and $\mathrm{B}$, respectively. The similarity coefficients were then used to construct a dendrogram using an unweight pair group method with the arithmetic average (UPGMA) through the sequential, hierarchical, agglomerative, and nested clustering (SHAN) routine of the NTSYS program.

To reveal the relationships between BCC and environmental variables (including the physical and chemical parameters), canonical correspondence analysis (CCA) was performed using CANOCO software (ver. 4.5, Microcomputer Power, Ithaca, NY, USA) as the length of the rst DCA axis run on species data was $>4$ (Ter Braak and Verdonschot, 1995). The binary matrix was constructed according to the cluster analyses. The environmental variables significantly related to the $\mathrm{BCC}$ were tested by forward selection and Monte Carlo permutation tests. The CCA was run separately for the datasets of each of the three sites.

Statistical analysis of the physical and chemical parameters was conducted using SPSS software, ver. 17.0 for Windows (Chicago, IL, USA). We tested the data nor- mality using Shapiro-Wilk tests, and then the differences in environmental parameters between sites were evaluated with $t$-tests. Significance was determined at an alpha level of $0.05(\mathrm{P}<0.05)$.

\section{Bacterial community diversity}

Gel images were analysed using Gel-Pro Analyzer (version 4.5). A densitometric curve was calculated for each lane, and the relative intensities of all bands were obtained. The Shannon-Wiener Index (H', bits) was calculated to estimate changes in bacterial community diversity using the following formula:

$$
\mathrm{H}^{\prime}=-\sum_{i=1}^{n} \mathrm{Pi} \ln \mathrm{Pi}
$$

where:

$\mathrm{Pi}$ is the relative intensity of each band; $\mathrm{n}$ is the total number of bands in each lane.

\section{RESULTS}

\section{Vertical properties of bulk parameters}

The vertical distributions of physicochemical and biological properties $\left(\mathrm{pH}, \mathrm{Eh}, \mathrm{TN}, \mathrm{TP}, \mathrm{TOC}, \mathrm{C} / \mathrm{N}, \delta^{13} \mathrm{C}, \mathrm{H}^{\prime}\right)$ of the sediments are shown in Fig. 2. The average and ranges of nutrient concentrations and ratios (TN, TP, TOC, $\left.\mathrm{C} / \mathrm{N}, \delta^{13} \mathrm{C}\right)$, physical parameters $(\mathrm{pH}$, Eh, water depth) and Shannon-Wiener diversity index ( $\left.\mathrm{H}^{\prime}\right)$ of each site are compiled in Tab. 1.

Site EH-1 in the northern end of Lake Erhai with an influx of OM pollution through non-point source agricultural run-off (Guo et al., 2001; Yang and Song, 2006) had the highest average values of $\mathrm{pH}, \mathrm{C} / \mathrm{N}$, and $\delta^{13} \mathrm{C}$ and the lowest values of TN, TOC and H'; Site EH-2 in the deepest point of the central lake had the highest average value of Eh and TP; Site EH-3 in the southern part of the lake had the highest average concentrations of TN and TOC and the lowest average values of $\mathrm{pH}, \mathrm{TP}, \mathrm{C} / \mathrm{N}, \delta^{13} \mathrm{C}$ and $\mathrm{H}^{\prime}$. The $\mathrm{Eh}, \mathrm{pH}$ and $\mathrm{C} / \mathrm{N}$ were significantly different $(\mathrm{P}<0.05)$ between Sites EH-1 and EH-2, as well as between Sites EH-1 and EH-3. The higher H' values coincided then with the highest nutrient and TOC concentration.

Vertical distributions of TOC and TN were highly variable with similar trends in both parameters at all sampling sites. There was a significant correlation between the concentration of TN and TOC (Sites EH-1: $\mathrm{r}=0.95$, $\mathrm{P}<0.01$; EH-2: $\mathrm{r}=0.88, \mathrm{P}<0.01$; EH-3: $\mathrm{r}=0.92, \mathrm{P}<0.01$ ). There were no significant differences $(\mathrm{P}>0.05)$ in the TOC concentrations among the three sites. An increase in the concentrations of TN and TOC were observed at $8-10 \mathrm{~cm}$ depth upward to the surface sediment sample at all sites, with the highest concentrations of TN and TOC found between the depths of 0 and $2 \mathrm{~cm}$ depths. Both the TN and 

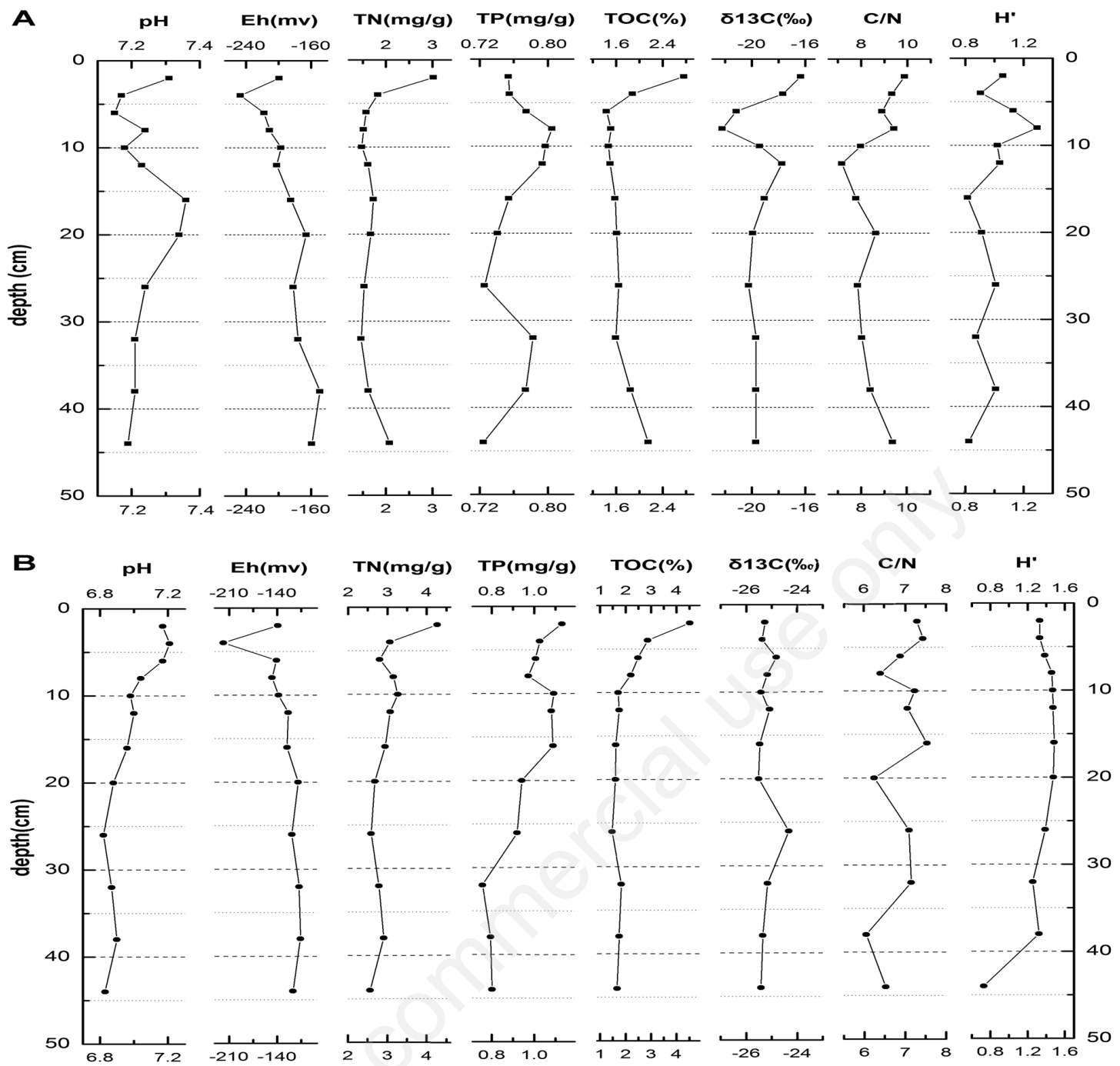

C
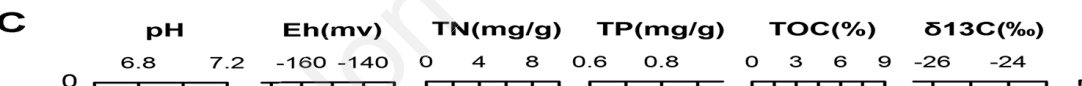

CIN

H'

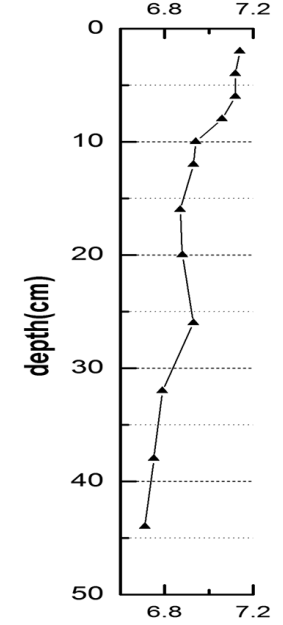

$\stackrel{-160-140}{,+1}$
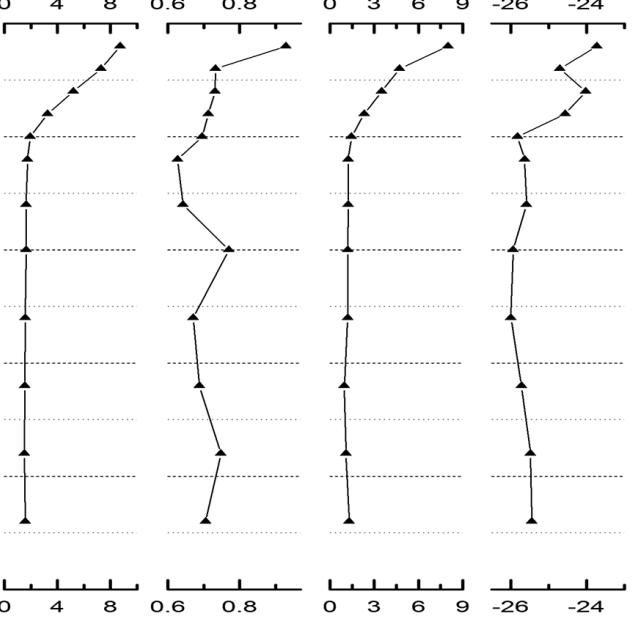

$\begin{array}{lllllll}6 & 7 & 8 & 9 & 0.0 & 0.6 & 1.2\end{array}$

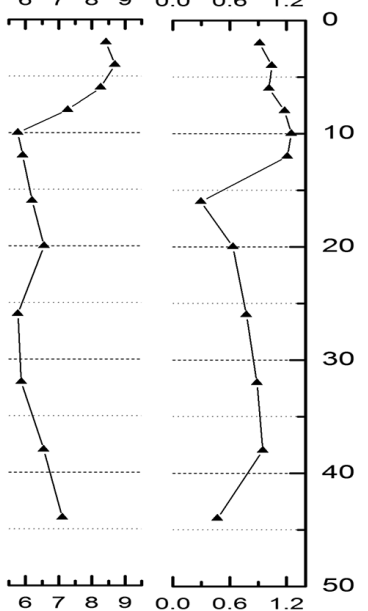

Fig. 2. Vertical properties of bulk parameters. Vertical changes in potential of hydrogen $(\mathrm{pH})$, oxidation-reduction potential (Eh), total nitrogen concentrations (TN), total phosphorus concentrations (TP), total organic carbon content (TOC), values of $\delta^{13} \mathrm{C}(\%) \mathrm{PDB}$, TOC:TN ratio $(\mathrm{C} / \mathrm{N})$, and Shannon-Wiener diversity index $\left(\mathrm{H}^{\prime}\right)$ of bacteria. The capital letters $\mathrm{A}, \mathrm{B}$ and $\mathrm{C}$ were used to distinguish the data from different Sites EH-1, EH-2 and EH-3, respectively. 
TOC showed high values in the H1 segment (from 10 to $0 \mathrm{~cm}$ sediment depths) and maintained a relatively stable value in the $\mathrm{H} 2$ segment (from 44 to $10 \mathrm{~cm}$ depths) at all sites (Fig. $2 \mathrm{~A}, \mathrm{~B}, \mathrm{C}$ ). The average concentrations of TOC $(4.0 \%)$ and $\mathrm{TN}(5.3 \mathrm{mg} / \mathrm{g})$ in the $\mathrm{H} 1 \mathrm{segment}$ were much higher than those in the H2 segment at Site EH-3 (TOC: $1.2 \%$ and TN: $1.6 \mathrm{mg} / \mathrm{g}$ ) (Fig. 2).

\section{Sediment dating}

The sediments in Lake Erhai were dated using ${ }^{137} \mathrm{Cs}$ and ${ }^{210} \mathrm{~Pb}$ (Wan, 1999; Xu et al., 1999). The dating results of the sediments are shown in Tab. 2. The sedimentation rates in Lake Erhai were calculated based on these age constraints.

\section{Vertical variations in diversity of bacterial communities}

The spatial variations in the Shannon-Wiener diversity index $\left(\mathrm{H}^{\prime}\right)$ of bacteria community are shown in Fig. 2. Variations in the Shannon-Wiener diversity index revealed a similar pattern at Sites EH-1 and EH-3. The index was lower at the bottom of the core and increased from $16 \mathrm{~cm}$ to the surface sediment. It reached a peak at $8-10 \mathrm{~cm}$ and gradually decreased upward. The variation trend in the Shannon-Wiener diversity index of the cores from Site EH2 was completely different from the other measured sites. The index was relatively stable and high at Site EH-2 $(\mathrm{P}<0.05)$.

\section{Composition of the bacterial community}

Visible changes were noted in the relative brightness and position of the DGGE banding patterns of $16 \mathrm{~S}$ rRNA gene fragments in various segments from the three sites (36 samples in total) (Supplementary Fig. 1). The cluster analysis (UPGMA) revealed remarkable spatial differences of BCC between different sites (Fig. 3). The bacterial communities in various layers from Site EH-1 (Fig. 3A) were grouped into 6 dened clusters. The samples from Site EH2 formed four separate clusters (Fig. 3B). The $38-44 \mathrm{~cm}$ sample (lowest measured TN, TOC and $\delta^{13} \mathrm{C}$ ) formed cluster 4. The samples from Site EH-3 distinctly formed three separate clusters along the depth gradient (Fig. 3C).

The bands from different layers at the same vertical position in a gel were assumed to have identical sequences (Riemann et al., 1999). Eighteen, twenty-five and fourteen bands from different vertical positions in the DGGE proles from Sites EH-1, EH-2 and EH-3, respectively, were excised, reamplified, purified and sequenced. In the DGGE proles, the first band obtained from Site EH-1 was indicated by EH-1-1. The other bands were named in the same manner. The phylogenetic affiliation of clones obtained from the DGGE proles at the three sites are shown in Tab. 3. The majority of the sequences were affiliated with phylogenetic groups commonly found in sediment: Deltaproteobacteria, Firmicutes and Chloroflexi. A total of 55 clones were classified into 28 OTUs, where 8 OTUs belonged to Deltaproteobacteria, followed by Firmicutes (5 OTUs) and Chloroflexi (5 OTUs). The taxonomic descriptions of the 55 bands obtained from the DGGE profiles of the three sampling sites are shown in Supplementary Tab. 1.

It has been suggested that band intensity is related to the relative abundance of the corresponding phylotype in the template mixture (Murray et al., 1996; Riemann et al. , 1999; Fromin et al., 2002), and thus the bands with relatively high intensities in a lane were assumed to belong to a dominant target. Deltaproteobacteria (bands EH1-11, EH-1-12 and EH-3-12) and Chloroflexi (bands EH-1-17, EH-3-3 and EH-3-8) were the most prominent when the values of TOC, $\delta^{13} \mathrm{C}$ and $\mathrm{C} / \mathrm{N}$ fluctuated (Site EH-1:0-12 cm; Site EH-3: 0-10 cm). When the values of TOC, $\delta^{13} \mathrm{C}$ and $\mathrm{C} / \mathrm{N}$ were relatively stable, Firmicutes (bands EH-1-3, EH-2-3 and EH-3-7) and Acidobacteria (bands EH-1-10, EH-2-6 and EH-2-12) were the most prominent. When the values of $\delta^{13} \mathrm{C}$ and $\mathrm{C} / \mathrm{N}$ were relatively stable but TOC fluctuated (Site EH-2: 0-8 cm), the

Tab. 1. Environmental parameters (mean and range) of the three sampling sites located in Lake Erhai.

\begin{tabular}{|c|c|c|c|c|c|c|}
\hline \multirow[t]{2}{*}{ Variable } & \multicolumn{2}{|c|}{ Site EH-1 } & \multicolumn{2}{|c|}{ Site EH-2 } & \multicolumn{2}{|c|}{ Site EH-3 } \\
\hline & Mean & Range & Mean & Range & Mean & Range \\
\hline Total nitrogen (mg/g) & 1.76 & $1.47 \sim 3.02$ & 2.21 & $2.56 \sim 4.27$ & 3.01 & $1.51 \sim 8.71$ \\
\hline Total phosphorus (mg/g) & 0.76 & $0.725 \sim 0.805$ & 0.97 & $0.757 \sim 1.131$ & 0.72 & $0.627 \sim 0.929$ \\
\hline Total organic carbon (\%) & 1.75 & $1.43 \sim 2.77$ & 2.12 & $1.47 \sim 4.52$ & 2.36 & $0.97 \sim 8.01$ \\
\hline$\delta^{13} \mathrm{C}(\%)$ & -19.3 & $-22.2 \sim-16.3$ & -23.8 & $-25.4 \sim-21.0$ & -25.2 & $-26.0 \sim-23.7$ \\
\hline $\mathrm{C} / \mathrm{N}$ & 8.5 & 7.2 9.9 & 7.0 & $6.2 \sim 7.5$ & 6.9 & $5.8 \sim 8.7$ \\
\hline Water depth (m) & & 11.2 & & 21 & & 8.3 \\
\hline $\mathrm{pH}$ & 7.2 & $7.2 \sim 7.4$ & 7.0 & $6.8 \sim 7.2$ & 6.9 & $6.7 \sim 7.1$ \\
\hline Eh (mv) & -191 & $-247 \sim-149$ & -156 & $-218 \sim-106$ & -133 & $-165 \sim-133$ \\
\hline Shannon-Wiener diversity index ( $\left.\mathrm{H}^{\prime}\right)$ & 0.99 & $0.82 \sim 1.30$ & 1.34 & $0.73 \sim 1.49$ & 0.88 & $0.30 \sim 1.25$ \\
\hline
\end{tabular}

$C / N$, TOC:TN ratio (TOC, total organic carbon content; $T N$, total nitrogen concentration). 
samples were more diverse and there was no obvious predominant band. Firmicutes (bands EH-3-5, EH-3-6, EH3-7 and EH-3-11) were observed almost throughout the core at Site EH-3.

\section{Canonical correspondence analysis}

Canonical correspondence analysis (CCA) based on DGGE data and environmental variables was carried out separately for the three sites. The results of CCA (Fig. 4) illustrate that the differences in the $\mathrm{BCC}$ were related to the three environmental variables $(\mathrm{TN}, \mathrm{TOC}$, and $\mathrm{C} / \mathrm{N}$; $\mathrm{P}<0.05$ ) at Site EH-1 (Fig. 4A). The three variables and the two axes explained $35 \%$ and $27 \%$ of the observed

Tab. 2. Dating results for sediments in Lake Erhai.

\begin{tabular}{llll} 
& \multicolumn{3}{c}{ Year } \\
Depth $(\mathrm{cm})$ & Site EH-1 & Site EH-2 & Site EH-3 \\
\hline 2 & 2001 & 1997 & 2000 \\
4 & 1993 & 1984 & 1992 \\
\hline 6 & 1985 & 1971 & 1984 \\
8 & 1978 & 1959 & 1976 \\
\hline 10 & 1970 & 1947 & 1968 \\
12 & 1962 & 1934 & 1960 \\
\hline 16 & 1943 & 1910 & 1936 \\
20 & 1926 & 1884 & 1908 \\
\hline 26 & 1906 & 1846 & 1870 \\
32 & 1880 & 1808 & 1834 \\
\hline Sedimentation rate $(\mathrm{cm} / \mathrm{y})$ & 0.25 & 0.16 & 0.18 \\
\hline
\end{tabular}

Tab. 3. Phyogenetic affiliation of clones obtained from the DGGE profiles at the three sampling sites.

\begin{tabular}{lccc} 
& \multicolumn{3}{c}{ No. of clones } \\
Taxon & Site EH-1 & Site EH-2 & Site EH-3 \\
Betaproteobacteria & 3 & 1 & 0 \\
Gammaproteobacteria & 0 & 1 & 0 \\
\hline Deltaproteobacteria & 6 & 6 & 1 \\
\hline Firmicutes & 3 & 3 & 4 \\
\hline Acidobacteria & 2 & 3 & 0 \\
Chloroflexi & 2 & 7 & 6 \\
\hline Bacteroidetes & 1 & 0 & 1 \\
Thermodesulfobacteria & 0 & 1 & 0 \\
\hline Spirochaetes & 0 & 0 & 1 \\
Bacillariophyta & 1 & 1 & 0 \\
\hline Actinobacteria & 0 & 1 & 0 \\
Total & 18 & 24 & 13 \\
\hline
\end{tabular}

$D G G E$, denaturing gradient gel electrophoresis. variation in $\mathrm{BCC}$, respectively. The first axis was positively related with the $\mathrm{TN}, \mathrm{TOC}$ and $\mathrm{C} / \mathrm{N}(\mathrm{r}=0.91,0.86$ and 0.75 , respectively). Alternatively, the results of CCA (Fig. 4B) illustrate that the differences in the $\mathrm{BCC}$ were related to the three environmental variables $(\mathrm{pH}, \mathrm{TP}$, and depth; $\mathrm{P}<0.05$ ) at Site EH-2 (depth as a catagorical variable). The three variables and the two axes explained $48 \%$ and $41 \%$ of the observed variation in BCC, respectively. The first axis was positively related to depth $(\mathrm{r}=0.98)$ and negatively related to TP $(\mathrm{r}=-0.93)$, and the second axis was positively related to $\mathrm{pH}(\mathrm{r}=0.63)$. Similarly, the results of CCA (Fig. 4C) indicated that the differences in $\mathrm{BCC}$ were related to the five environmental variables $(\mathrm{pH}$,

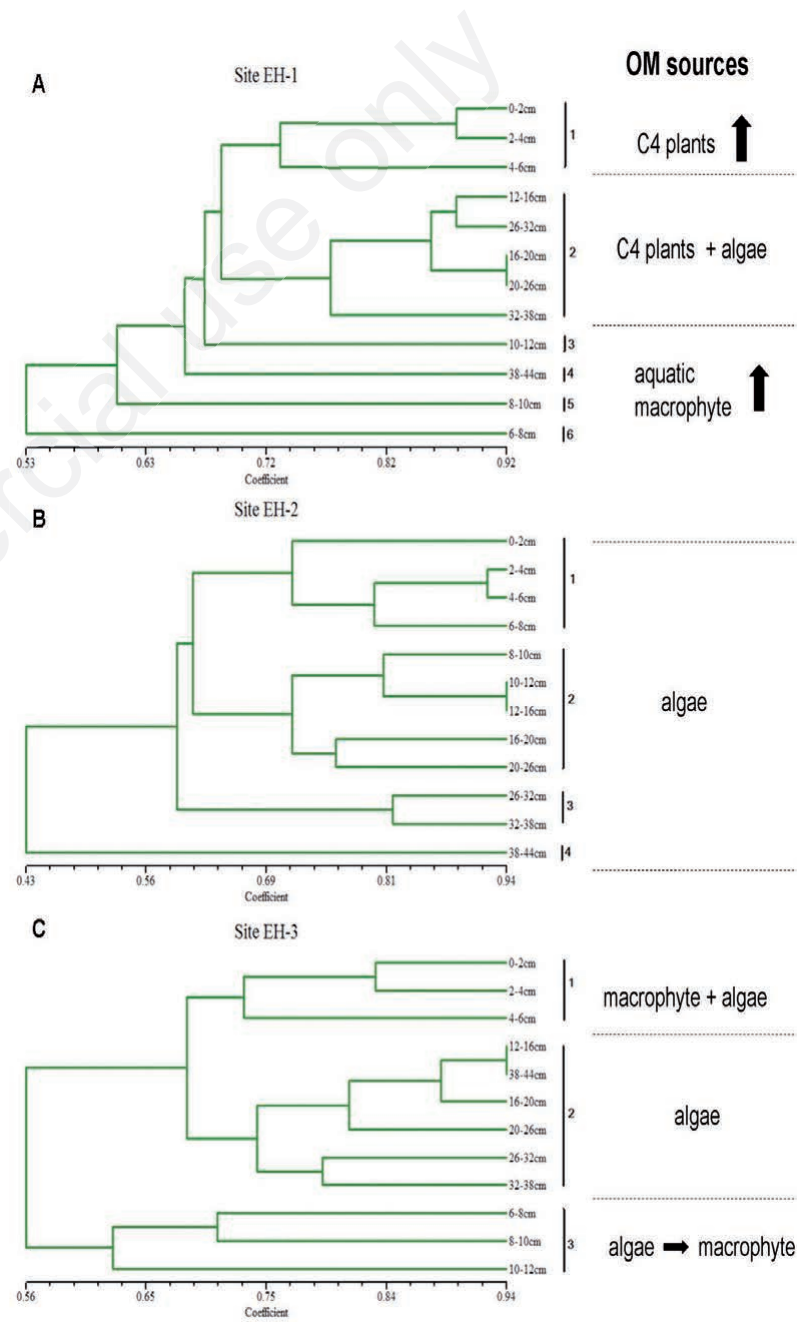

Fig. 3. Cluster analysis of bacterial community composition based on denaturing gradient gel electrophoresis (DGGE) profiles. The cluster results of bacterial community composition (BCC) with depths are shown. The capital letters A, B and C were used to distinguish the data of different Sites EH-1, EH-2 and EH-3, respectively. Organic matter (OM) sources in different segment of the cores are showed at the right side, the up arrow represent the increase of the OM source, the right arrow represent the succession of the OM source. 
$\mathrm{C} / \mathrm{N}, \delta^{13} \mathrm{C}, \mathrm{TN}$, and depth; $\left.\mathrm{P}<0.05\right)$ at Site $\mathrm{EH}-3$. The five variables and the two axes explained $51 \%$ and $28 \%$ of the observed variation in $\mathrm{BCC}$, respectively. The first axis was positively related to depth $(\mathrm{r}=0.86)$, and the second axis was negatively related to the $\mathrm{pH}, \mathrm{C} / \mathrm{N}, \delta^{13} \mathrm{C}$ and $\mathrm{TN}$ $(\mathrm{r}=-0.93,-0.79,-0.77$ and -0.69 , respectively).

The CCA biplot revealed that the samples from Sites EH-1 and EH-2 formed three clusters, whereas Site EH3 formed two clusters (Fig. 4). The samples collected at Site EH-1 from 2 to $10 \mathrm{~cm}$ and from 12 to $20 \mathrm{~cm}$ formed one cluster, whereas the remaining samples (except the $0 \sim 2 \mathrm{~cm}$ sample) formed the second cluster. The $0 \sim 2 \mathrm{~cm}$ sample was quite different from the others due to its high concentrations of TN and TOC. The samples collected at Site EH-2 were grouped into 3 clusters. Cluster 1 consisted of samples from 0 to $8 \mathrm{~cm}$, cluster 2 contained samples from 8 to $26 \mathrm{~cm}$, and cluster 3 was composed of samples from 26 to $44 \mathrm{~cm}$. These results are similar to those obtained via the cluster analysis of $\mathrm{BCC}$ based on the DGGE proles (Fig. 3B). The samples collected at Site EH-3 grouped into two clusters. Cluster 1 consisted of samples from 0 to $8 \mathrm{~cm}$, and cluster 2 contained samples from 8 to $44 \mathrm{~cm}$ (Fig. 4C).

\section{DISCUSSION}

In recent years, Lake Erhai has been considered as a transitional body of water, shifting between a mesotrophic and eutrophic state (Pan et al., 1999). Lake Erhai is a closed or semi-closed plateau lake, whose sediment records provide a sensitive indicator of environmental changes, as well as fine- and high-resolution information (Chen and Wan, 1999). Several studies have investigated the climate and environmental changes recorded in Lake Erhai sediment by determining OM source and characterisation (Fu et al., 2006; Kitagawa et al., 2007; Guo et al., 2011). Our study not only detected the variation in OM sources with depth but also revealed the major driving factors for bacterial community composition in the sediment of Lake Erhai.

\section{$\mathrm{C} / \mathrm{N}$ and $\delta^{13} \mathrm{C}$ identifiers of organic matter source}

In general, the $\mathrm{C} / \mathrm{N}$ value can be used to distinguish between aquatic and terrestrial sources of $\mathrm{OM}$ in lacustrine environments (Meyers and Lallier-Vergès, 1999; Filippi and Talbot, 2005). Protein-rich lake phytoplankton have $\mathrm{C} / \mathrm{N}$ values between 4 and 10 , whereas the $\mathrm{C} / \mathrm{N}$ values of higher plants on land, which are cellulose-rich and proteinpoor, have $\mathrm{C} / \mathrm{N}$ atomic ratios of $>20$ (Meyers and Ishiwatari, 1993). In contrast, the $\mathrm{C} / \mathrm{N}$ values in aquatic macrophytes are higher than phytoplankton (Hedges et al., 1988; Meyers, 1994). This distinction arises from the absence of cellulose in algae and its abundance in vascular plants. All the $\mathrm{C} / \mathrm{N}$ ratios of the three sites are less than 10 , with average values of 8.5 (Site EH-1), 7.0 (Site EH-2) and 6.9 (Site EH-3) $(n=12)$ (Tab. 1). The values throughout the cores suggested that the contributors of sedimentary OM were predominantly aquatic sources.

Isotopic signatures of photosynthetically fixed organic

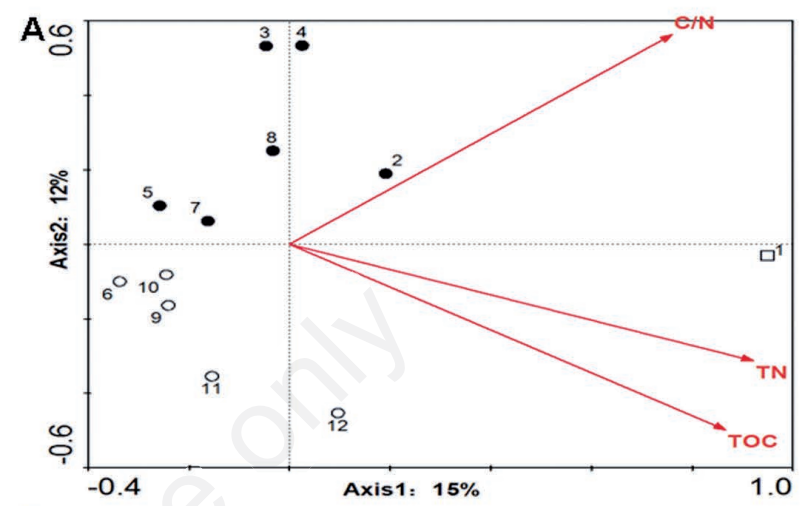

B

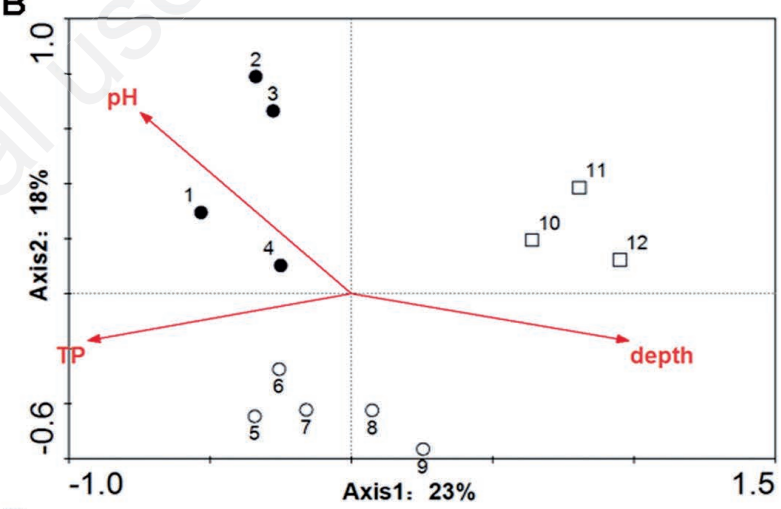

C

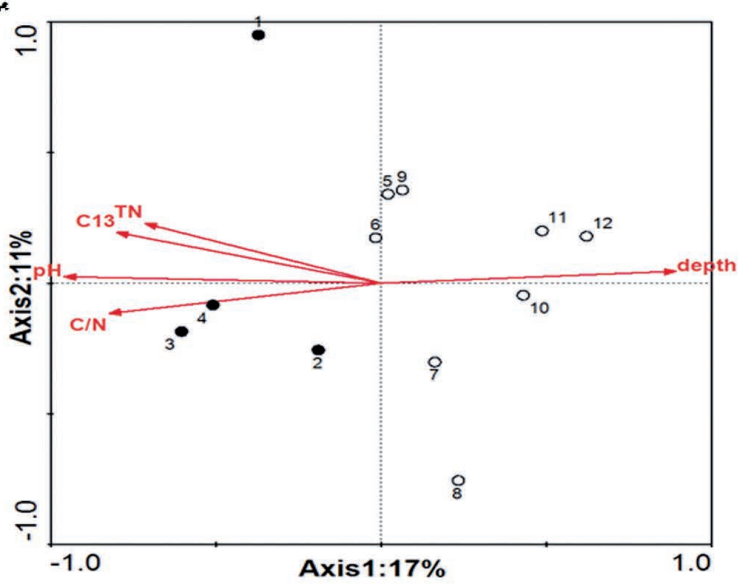

Fig. 4. Canonical correspondence analysis (CCA) biplot based on data from the denaturing gradient gel electrophoresis and environmental variables. The capital letters A, B and C were used to distinguish the data of different Sites EH-1, EH-2 and EH-3, respectively. The spots represent sediment samples in different layers. 1, 0 2 cm; 2, 2 4 cm; 3, 4 6 cm; 4, 6 8 cm; 5, 8 10 cm; 6, 10 12 cm; 7, 12 16 cm; 8, 16 20 cm; 9, 20 26 cm;10, $26 \sim 32 \mathrm{~cm} ; 11,32 \sim 38 \mathrm{~cm} ; 12,38 \sim 44 \mathrm{~cm}$. 
carbon offer opportunities to trace sources of OM in sediment. Carbon isotopic ratios are useful for distinguishing between lacustrine and continental plant sources of sedimentary organic matter (Meyers, 1994). Algal organic matter typically has a distinctly different carbon isotopic composition than material produced by $\mathrm{C} 4$ plants growing either on land or the lake bottom (Meyers and LallierVergès, 1999). The isotope carbon ratios for the $\mathrm{C} 4$ pathway is -10 to $-15 \%$, whereas that of the CAM pathway can vary from $-10 \%$ o $20 \%$; the $\mathrm{C} 3$ pathway has a variability of -24 -30\% (Fontugne and Jouanneau, 1987). Lake sediments with multiple sources of OM have variable $\delta^{13} \mathrm{C}$ values (Talbot and Johannessen, 1992). OM produced by land plants using the $\mathrm{C} 3$ pathway consequently has an average $\delta^{13} \mathrm{C}(\mathrm{PDB})$ value of ca $-28 \%$, and the $\mathrm{OM}$ of plants using the $\mathrm{C} 4$ pathway has an average $\delta^{13} \mathrm{C}(\mathrm{PDB})$ value of ca $-14 \%$ (O'leary, 1988). Because submerged plants use carbon dioxide and carbonate in lake water to produce carbohydrate through photosynthesis, the $\delta^{13} \mathrm{C}$ value is relatively positive; however, phytoplankton use atmospheric $\mathrm{CO}_{2}$ for photosynthesis, thus resulting in more negative values of $\delta^{13} \mathrm{C}$ (Stuiver, 1975). The $\delta^{13} \mathrm{C}$ values for algae, which are similar to $\mathrm{C} 3$ plants, are below $-25 \%$ (Lücke et al., 2003).

Origin of sedimentary organic matter from aquatic as opposed to land sources can be distinguished by the characteristic $\mathrm{C} / \mathrm{N}$ ratio compositions and carbon isotopic ratios (Fig. 5). The $\mathrm{C} / \mathrm{N}$ and $\delta^{13} \mathrm{C}$ values both increased from $6 \mathrm{~cm}$ to $0 \mathrm{~cm}$ of the sediment at Site EH-1, indicating a rise in the relative proportion of $\mathrm{OM}$ derived from $\mathrm{C} 4$ plants $\left(\delta^{13} \mathrm{C}\right.$ ranged from -10 to $\left.-15 \%\right)$. An increase in the $\mathrm{C} / \mathrm{N}$ ratios coupled with a decrease in the $\delta^{13} \mathrm{C}$ values from $12 \mathrm{~cm}$ to $6 \mathrm{~cm}$ of the sediment suggested growth in the proportion of $\mathrm{OM}$ derived from aquatic macrophytes. The $\delta^{13} \mathrm{C}$ values (-22.2 -16.3\%) and $\mathrm{C} / \mathrm{N}$ ratios recorded in the lower layers indicate that the source of OM is a mixture of $\mathrm{C} 4$ plant-derived and plankton-derived organic carbon (Fig. 2A). All C4 plants have a significant advantage over $\mathrm{C} 3$ plants under low atmospheric $\mathrm{CO}_{2}$ condition and have the ability to evade drought. Within the monocots, $\mathrm{C} 4$ photosynthesis is quite common among grasses (Poaceae) and sedges (Cyperaceae) (Hattersley and Watson, 1992), for examples, corn (Zea mays), Cyperis rothundus and Heleocharis dulcis. Site EH-1 was located at the alluvial fan of the Yongan River and has an influx of OM pollution through non-point source agricultural run-off. It was also reported that the sources of sedimentary organic matter of Lake Erhai changed due to changes in terrestrial vegetation composition (Tareq et al., 2011). We speculated that the $\mathrm{C} 4$ plant-derived OM observed at Site EH-1 were mainly from the water-carried plant debris by fluvial action of the inflowing rivers and terrestrial runoff. According to the dating data, the segment (6-12 cm depths) of the core covered the period from 1972-
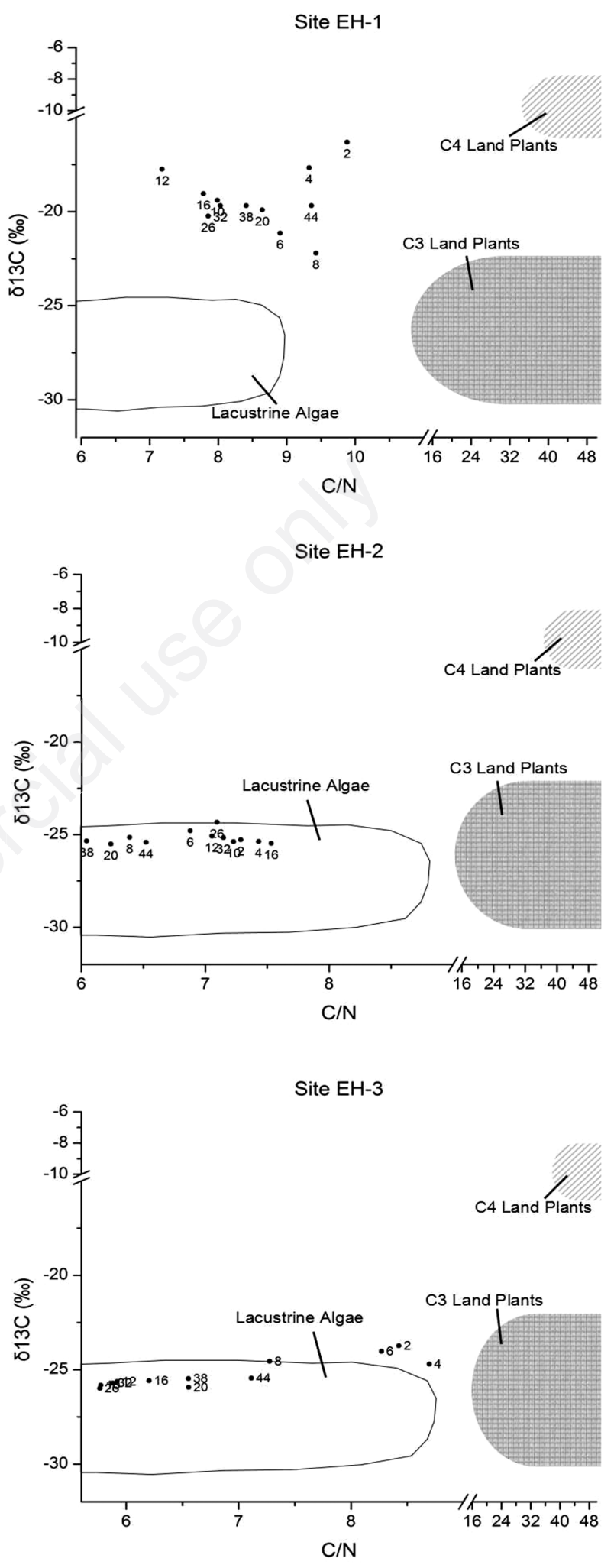

Fig. 5. $\mathrm{C} / \mathrm{N}$ ratio and carbon isotopic compositions of organic matter from lacustrine algae, $\mathrm{C} 3$ land plants, $\mathrm{C} 4$ land plants that use $\mathrm{CO}_{2}$ as their source of carbon during photosynthesis, and sediment samples of different depths. The spots represent sediment samples in different depths. 
1982. The water level dropped during this period (Li Y. et al., 2011), which could explain the growth in the proportion of OM derived from aquatic macrophytes in the lower (6-12 cm depths) part of the core.

The $\mathrm{C} / \mathrm{N}$ ratios were smaller than 7 , and the $\delta^{13} \mathrm{C}$-values were below $-25 \%$ across the core from Site EH-2, clearly indicating that the $\mathrm{OM}$ consistently had an algae origin (Fig. 2B). The identical changes in the $\mathrm{C} / \mathrm{N}$ and $\delta^{13} \mathrm{C}$ values revealed that the $\mathrm{OM}$ was also mostly derived from algae in the lower (below $10 \mathrm{~cm}$ ) parts of the core from Site EH3. An increase in the $\mathrm{C} / \mathrm{N}$ ratio and $\delta^{13} \mathrm{C}$ values was observed from samples taken from $10 \mathrm{~cm}$ below the interface up to surface sediment sample, indicating a change from algae to macrophytes as the major source of OM (Fig. 2C). The segment (6-10 cm depths) of the core covered the period from 1972-1982. As we mentioned above, the water level dropped during this period. Our result was consistent with the observation that the submersed macrophyte communities appeared before the year 2000 at Site EH-3. Water level rose from 1983 to 2006, during the fall of 1996, 1998, 2003, and 2006, there were four lake- wide Anabaena spp. bloom breakouts, especially in 1998 when the bloom lasted for more than 50 days (Wang et al., 2011). An decrease in the $\mathrm{C} / \mathrm{N}$ ratio from $4 \mathrm{~cm}$ up to surface sediment indicated that the growth in the proportion of OM derived from algae during the 1994-2006 time period. These results maybe the main reason why the submersed macrophyte communities in these zones gradually disappeared during the 2003-2006 time period.

\section{Environmental factors regulating the bacterial community composition}

Canonical correspondence analysis is a powerful tool to illustrate how bacterial community structure varies along gradients of environmental variables (Salles et al., 2004). The CCA results in this study revealed that the TN, TOC, $\mathrm{C} / \mathrm{N}, \delta^{13} \mathrm{C}, \mathrm{pH}$ and $\mathrm{TP}$, as well as depth significantly influenced $\mathrm{BCC}(\mathrm{P}<0.05)$ in the lake sediments. We also observed that the depth-related BCC in different locations of Lake Erhai were significantly influenced by different environmental factors (Fig. 4 A,B,C).

The vertical profile of $\mathrm{BCC}(\mathrm{P}<0.05)$ in the sediment at Site EH-1 was significantly influenced by the content of TOC, TN and the $\mathrm{C} / \mathrm{N}$ ratio (Fig. 4A), indicating that both the content and source of OM have important influence on the microbial community structure. As mentioned above, the source of OM at Site EH-1 was a mixture of autochthonous and terrestrial organic carbon, both of which had an indirect effect on the bacterial community composition (Rooney-Varga et al., 2005). Thus, changes in the content of organic carbon derived from different sources result in variations in the composition of the bacterial communities utilising the OM at Site EH-1. Similarly, the concentration of $\mathrm{TN}, \mathrm{C} / \mathrm{N}$ ratio and the $\delta^{13} \mathrm{C}$ values at Site EH-3 were significantly related to the $\mathrm{BCC}$ $(\mathrm{P}<0.05)$; however, the concentration of TOC at Site EH3 was not significantly related to $\mathrm{BCC}(\mathrm{P}>0.05)$ (Fig. 4C), which demonstrated that the sediment bacterial community at Site EH-3 was much more sensitive to the content of TN than the content of TOC. These results suggested that the concentration of TN and OM sources, rather than the content of OM, had a pronounced impact on the vertical changes in $\mathrm{BCC}$ in the underwater platform of south Lake Erhai.

Our study indicated that TP significantly influenced $(\mathrm{P}<0.05)$ the sediment BCC at Site EH-2 (Fig. 4B). The concentration of TP explained over $20 \%$ of the observed variation in $\mathrm{BCC}$ at this site, indicating that the concentration of TP may be the major shaping force in the deepest point in middle Lake Erhai. The effect of TP on the diversity and composition of bacterial communities has been reported (Lindström and Bergström, 2005), they noted that TP concentration statistically explained the differences between the microbial community compositions in two different drainage areas. The TP values were significantly higher $(\mathrm{P}<0.05)$ at Site EH-2 (Tab. 1) compared to the other sites, which suggests that the substrate phosphorus content is rich in middle lake sediment. Moreover, the concentrations of TP in the $0-26 \mathrm{~cm}$ sediment layers were greater than those in the $26-44 \mathrm{~cm}$ layers (Fig. 2B). The measurement of BCC in samples with a higher phosphorus content $(0-20 \mathrm{~cm})$ were positively related with $\mathrm{TP}$, whereas the $\mathrm{BCC}$ in layers with a lower phosphorus content $(20-44 \mathrm{~cm})$ were negatively related with TP (Fig. 4B). Our results indicate the sediment bacterial community composition was directly driven by the total phosphorus concentration rather than the content and source of OM in middle lake sediment. We speculated that at the deepest point of the lake, the $\mathrm{P}$ contained in organic matter that reaches the bottom is of a lower concentration because they remain in the water column longer; thus, there is more time to be degraded by planktonic bacteria. Therefore, the bottom bacteria are limited by this nutrient.

The CCA results revealed that $\mathrm{pH}$ has a pronounced impact on the bacterial community composition $(\mathrm{P}<0.05)$ at Site EH-2 and EH-3 (Figs. 4 B,C). pH may not only reflect changes in other environmental factors (KoskiVähälä et al., 2001), which can have both inhibitory and stimulative effects on bacterial communities (Zeng et al., 2009), but may also influence bacterial communities through direct biological mechanisms (Yannarell and Triplett, 2005).

We found that depth was one of the most influential factors $(\mathrm{P}<0.05)$ on sediment $\mathrm{BCC}$ at sites $\mathrm{EH}-2$ and $\mathrm{EH}-$ 3 (Fig. 4 B,C). Our results agree with the observation of several studies that BCC in sediment is related to a depth gradient (Hewson and Fuhrman, 2006; Zhao et al., 2008; Liu et al., 2010). The depth gradients in redox potential 
and oxygen concentration should consistently affect the vertical distribution of bacterial communities (Tšertova et al., 2013). Nevertheless, the CCA results suggested that depth did not have a marked effect on BCC in the sediments at Site EH-1. Site EH-1 is located in Hongshan Bay, which is the lower edge of the alluvial fan of the Yongan River. This area has an influx of OM pollution through non-point source agricultural run-off. We assume that ambient interference is efficient at vertically shaping bacterial communities, and the intensive resuspension of the soft sediment is a major factor that causes the homogeneous community distribution.

\section{Taxonomic groups and their distribution associated with organic matter sources}

In the present study, the majority of the bacteria sequences obtained from the three sampling sites were affiliated with the divisions Proteobacteria, Firmicutes, and Chloroflexi (Tab. 3). Clones affiliated with Acidobacteria, Bacteroidetes, Thermodesulfobacteria, Spirochaetes and Actinobacteria were also found in low numbers $(<6$ sequences per division).

A total of 18 clones were affiliated with Proteobacteria, and most of these clones were from the subdivision $\delta$-Proteobacteria (Supplementary Fig. 2). The majority of the $\delta$ Proteobacteria sequences fell into two distinct families, Pelobacteraceae and Desulfobacteraceae, both of which are sulphate-reducing bacteria. Sulphur-reducing bacterial communities are important in organic carbon oxidation in sediments. This observation is supported by strong evidence that sulphates are one of the main electron acceptors present in these environments (Ghosh et al., 2010). The oxidation of reduced S species and/or sulphur-reduction is thought to be essential for energetic metabolism in these areas (LópezGarcía et al., 2003). In the present study, we found that 4 of the $5 \delta$-Proteobacteria clones (bands EH-1-11, EH-1-12, EH-1-16 and EH-1-18) at Site EH-1 seemed to be predominant in the middle part (6-12 cm depth) of the core and then decreased upward to the water-sediment interface. One clone (band EH-1-16) was absent in shallower sediment levels (Supplementary Fig. 1A). In total, $6 \delta$-Proteobacteria clones (bands EH-2-13, EH-2-14, EH-2-15, EH-2-19, EH2-20 and EH-2-22) at Site EH-2 appeared in all layers throughout the core. As mentioned above, the OM in the middle (6-12 cm depth) part of the core from Site EH-1 mainly originated from aquatic macrophytes, and $\mathrm{C} 4$ plants contributed to the increased sediment OM in the upper (0-6 $\mathrm{cm}$ depths) portion of the core. By contrast, the $\mathrm{OM}$ at Site EH-2 originated from algae across all sediment layers investigated in this study (Fig. 2 A,B). It was reported that compared to autochthonous OM, terrestrial carbon is relatively more resistant to biodegradation due to its complex structure (Meyers, 1994; Mccallister et al., 2006). The cultured members of sulphur-reducing bacterial families pre- dominantly oxidise low-molecular-weight organic acids, and their substrate range does not include high molecular weight carbohydrates in the sediment (Widdel and Bak, 1992), which may explain the decreased abundance of $\delta$ Proteobacteria subdivisions coinciding with the elevated proportions of $\mathrm{C} 4$ plant-derived organic carbon (Fig. 2A).

A total of four clones grouped in the $\beta$-Proteobacteria and one clone in the $\gamma$-Proteobacteria subdivisions were detected at the three sites (Tab. 3). The members of the $\beta$ Proteobacteria constituted an important fraction in the sediments of the more eutrophic reservoirs, whereas $\gamma$-subgroup Proteobacteria were most frequently detected in sediment samples from the dystrophic reservoir (Wobus et al., 2003). In our study, 3 of the 4 clones grouped in the $\beta$ Proteobacteria subdivisions and no clone belonging to $\gamma$ Proteobacteria were observed in the sediment at Site EH-1 (Tab. 3), indicating that the water body at Site EH-1 was eutrophic. Our results agree with the observation of several studies that the water quality in the northern area of Lake Erhai has deteriorated (Guo et al., 2001, Yang and Song, 2006). In Addition, we found that all $\beta$-Proteobacteria clones (bands EH-1-6, EH-1-7, EH-1-8, EH-1-9, EH-2-4) detected in our study appeared as prominent phylotypes in the upper sediments (Supplementary Fig. 1 A,B). The results agree with previous reports that $\beta$-Proteobacteria was the predominant group in upper sediments (Liu et al., 2010); the prevalence of $\beta$-Proteobacteria might be a general feature of microbial communities in habitats with high loads of organic carbon. DGGE is not sufficient to catch the whole community composition and reveals only the most abundant taxons. Thus, there could be other results when using another method.

It was reported that Chloroflexi are likely to contribute to the diversified repertoire of polysaccharide hydrolases in sediments (Teske et al., 2011). Chloroflexi are a dominant microbial community component of deep marine sediments and include obligate anaerobic dehalogenators and diverse sugar and amino acid fermenters within the recently defined class Anaerolineae (Teske, 2006). Anaerolineae are often isolated from anaerobic digesters in wastewater treatment plants or from industrial fermenting bioreactors; some recently isolated strains within Anaerolineae are able to grow slowly on xylan and starch (Yamada et al., 2006). Clones affiliated with the class Anaerolineae of the Chloroflexi phylum were also detected in our study (Supplementary Fig. 2). Several uncultured Chloroflexi populations were shown to express chitinase, esterase, galactosidase, and glucuronidase activity (Kragelund et al., 2007). Therefore, in the present study, Chloroflexi was the most prominent when both the source and content of OM changed. In total, $30 \%$ and $46 \%$ of the clones grouped in the Chloroflexi were detected at Site EH-2 and EH-3, respectively, indicating that the sedimentary microbial communities at the two sites had broad enzymatic capabilities 
on diversified $\mathrm{OM}$. This result may explain why the $\mathrm{BCC}$ in the sediments from Site EH-2 and Site EH-3 were not sensitive to the content of TOC.

Firmicutes are seldom discussed in previous studies of microbial ecology due to their low frequencies in the libraries (Eiler and Bertilsson, 2004; Wu et al., 2007). Nevertheless, three, three and four clones were detected in our study at Sites EH-1 EH-2 and EH-3, respectively (Tab. 3). Most of the clones fell into the class Bacilli, may be that Bacilli sequences found in the sediments belonged to spores from soil-derived Bacilli. It was reported that members of the Firmicutes assimilate algal extracts quickly (Teske et al., 2011). In the present study, the appearance of Firmicutes in all layers of the core from all sites suggested that their distributions were not significantly influenced by the OM source.

\section{The relationship between the organic matter sources and the diversity of bacterial community}

In the present study, no significant correlation $(\mathrm{P}<0.05)$ could be observed between the physicochemical parameters and the diversity of the bacterial community $\left(\mathrm{H}^{\prime}\right)$ at all the observed sites, which was consistent with a previous study in sediment of Lake Taihu by Zhao et al. (2008). They speculated that the bacterial community structure in sediment was primarily regulated by integrative conditions rather than a single factor. Nevertheless, we also found that the bacterial community diversity was directly influenced by the OM source. The constant OM sources at Site EH-2 resulted in a stable higher diversity of the bacterial community as compared to other two sites, whereas the variable OM sources at Sites EH-1 and EH-3 contributed to the changes in H'. We can conclude that differences in the diversity of bacterial communities in samples differing in their source of $\mathrm{OM}$ were related to environmental variables (e.g., water level, river runoff and terrestrial vegetation composition). The greater number of phylum- and subphylum-level lineages and operational taxonomic units in Site EH-2 compared to the other sites may reflect a wider range of enzymatic capabilities and strategies to access OM.

\section{CONCLUSIONS}

Our detailed field survey on the relationships between depth-related bacterial community composition and physicochemical parameters showed that the depth-related variation in sediment bacterial communities in different areas of the lake was significantly influenced by varying environmental factors, however, the OM sources played important roles in structuring the $\mathrm{BCC}$ at all the sites. The sequencing of DGGE bands suggested that the majority of the sequences were affiliated with the following common phylogenetic groups in lake sediment: Chloroflexi, Deltaproteobacteria, and Firmicutes. The DGGE banding patterns revealed that the abundance of Deltaproteobacteria decreased with accompanying elevated levels of $\mathrm{C} 4$ plant-derived organic carbon. The Shannon-Wiener diversity index of bacterial communities was directly affected by the OM source, and constant OM sources resulted in a stable higher diversity of bacterial community. These may lead to broader understanding of microbial community structure and ecosystem functioning in mesotrophic lakes, although the mechanisms need further investigations.

\section{ACKNOWLEDGMENTS}

This study was supported by National Water Pollution Control and Management Technology Major Projects of China (2008ZX07105-005). We are grateful to Dr. Yuanying Shen, Haoxiang Luo for allowing us to use their lab, Wenbin Liu, Bin Hu, Haiping Hu, Tai Zhang, Chaonan Cui for their help on sample collection, Sam Miller and Josh Goldberger for providing language help.

\section{REFERENCES}

Bååth E, Frostegård A, Pennanen T, Fritze H, 1995. Microbial community structure and $\mathrm{pH}$ response in relation to soil organic matter quality in wood-ash fertilized, clear-cut or burned coniferous forest soils. Soil Biol. Biochem. 27:229-240.

Chen JA, Wan G, 1999. Sediment particle size distribution and its environmental significance in Lake Erhai, Yunnan Province. Chinese J. Geochem. 18:314-320.

Dearing JA, Jones RT, Shen J, Yang X, Boyle JF, Foster GC, Elvin MJD, 2008. Using multiple archives to understand past and present climate-human-environment interactions: the lake Erhai catchment, Yunnan Province, China. J. Paleolimnol. 40:3-31.

Delong EF, Pace NR, 2001. Environmental diversity of bacteria and archaea. Systematic Biol. 50:470-478.

Dorigo U, Volatier L, Humbert JF, 2005. Molecular approaches to the assessment of biodiversity in aquatic microbial communities. Water Res. 39:2207-2218.

Eiler A, Bertilsson S, 2004. Composition of freshwater bacterial communities associated with cyanobacterial blooms in four Swedish lakes. Environ. Microbiol. 6:1228-1243.

Fang J, Barcelona MJ, Nogi Y, Kato C, 2000. Biochemical implications and geochemical significance of novel phospholipids of the extremely barophilic bacteria from the Marianas Trench at 11,000 m. Deep-Sea Res. PT. I 47:1173-1182.

Filippi ML, Talbot MR, 2005. The palaeolimnology of northern Lake Malawi over the last $25 \mathrm{ka}$ based upon the elemental and stable isotopic composition of sedimentary organic matter. Quaternary Sci. Rev. 24:1303-1328.

Fontugne MR, Jouanneau JM, 1987. Modulation of the particulate organic carbon flux to the ocean by a macrotidal estuary: evidence from measurements of carbon isotopes in organic matter from the Gironde system. Estuar. Coast. Shelf S. 24:377-387.

Fromin N, Hamelin J, Tarnawski S, Roesti D, Jourdain-Miserez K, Forestier N, Rossi P, 2002. Statistical analysis of denaturing gel electrophoresis (DGE) fingerprinting patterns. Environ. Microbiol. 4:634-643. 
Fry B, Sherr EB. 1989. $\delta^{13} \mathrm{C}$ measurements as indicators of carbon flow in marine and freshwater ecosystems, p. 196-229. In: P.W. Rundel, J.R. Ehleringer and K.A. Nagy (eds.), Stable isotopes in ecological research. Springer, New York.

Fu P, Wu F, Liu CQ, Wei Z, Bai Y, Liao H, 2006. Spectroscopic characterization and molecular weight distribution of dissolved organic matter in sediment porewaters from Lake Erhai, Southwest China. Biogeochemistry 81:179-189.

Ghosh A, Dey N, Bera A, Tiwari A, Sathyaniranjan K, Chakrabarti K, Chattopadhyay D, 2010. Culture independent molecular analysis of bacterial communities in the mangrove sediment of Sundarban, India. Saline Systems 6:1.

Guo HC, Liu L, Huang GH, Fuller GA, Zou R, Yin YY, 2001. A system dynamics approach for regional environmental planning and management: a study for the Lake Erhai Basin. J. Environ. Manage. 61:93-111.

Guo J, Liang Z, Liao H, Tang Z, Zhao X, Wu F, 2011. Sedimentary record of polycyclic aromatic hydrocarbons in Lake Erhai, Southwest China. J. Environ. Sci. 23:1308-1315.

Hattersley PW, Watson L. 1992. Grass evolution and domestication, p. 38-116. In: G. Chapman (ed.), Diversification of photosynthesis Cambridge University Press.

Hedges JI, Clark WA, Cowie GL, 1988. Organic matter sources to the water column and surficial sediments of a marine bay. Limnol. Oceanogr. 33:1116-1136.

Hedges JI, Keil RG, 1995. Sedimentary organic matter preservation: an assessment and speculative synthesis. Mar. Chem. 49:81-115.

Hedges J, Keil RG, Benner R, 1997. What happens to terrestrial organic matter in the ocean? Org. Geochem. 27:195-212.

Hewson I, Fuhrman JA, 2006. Spatial and vertical biogeography of coral reef sediment bacterial and diazotroph communities. Mar. Ecol. - Prog. Ser. 306:79-86.

Jin XC, Tu QY, 1990. The Standard Methods for Observation and Analysis of Lake Eutrophication, Seconded. China Environmental Science Press, Beijing, China (In Chinese).

Kao CM, Chen SC, Liu JK, Wang YS, 2001. Application of microbial enumeration technique to evaluate the occurrence of natural bioremediation. Water Res. 35:1951-1960.

Kao CM, Prosser J, 1999. Intrinsic bioremediation of trichloroethylene and chlorobenzene: field and laboratory studies. J. Hazard. Mater. 69:67-79.

Kitagawa H, Tareq SM, Matsuzaki H, Inoue N, Tanoue E, Yasuda Y, 2007. Radiocarbon concentration of lake sediment cellulose from Lake Erhai in southwest China. Nucl. Instrum. Meth. B 259:526-529.

Koizumi Y, Kojima H, Fukui M, 2003. Characterization of depth-related microbial community structure in lake sediment by denaturing gel electrophoresis of amplified 16S rDNA and reversely transcribed 16S rRNA fragments. FEMS Microbiol. Ecol. 46:147-157.

Koski-Vähälä J, Hartikainen H, Tallberg P, 2001. Phosphorus mobilization from various sediment pools in response to increased $\mathrm{pH}$ and silicate concentration. J. Environ. Qual. 30:546-552.

Kragelund C, Levantesi C, Borger A, Thelen K, Eikelboom D, Tandoi V, Nielsen PH, 2007. Identity, abundance and ecophysiology of filamentous Chloroflexi species present in activated sludge treatment plants. FEMS Microbiol. Ecol. 59:671-682.
Lücke A, Schleser GH, Zolitschka B, Negendank JF, 2003. A Lateglacial and Holocene organic carbon isotope record of lacustrine palaeoproductivity and climatic change derived from varved lake sediments of Lake Holzmaar, Germany. Quaternary Sci. Rev. 22:569-580.

López-García P, Duperron S, Philippot P, Foriel J, Susini J, Moreira D, 2003. Bacterial diversity in hydrothermal sediment and epsilonproteobacterial dominance in experimental microcolonizers at the Mid-Atlantic Ridge. Environ. Microbiol. 5:961-976.

Li E, Wang X, Cai X, Wang X, Zhao S, 2011. [Features of aquatic vegetation and the influence factors in Erhai lakeshore wetland].[Article in Chinese]. J. Lake Sci. 23:738-746.

Li Y, Wang Z, Hu M, Chang F, Liu Y, Li G, Li D, Shen Y, 2011. Diversity and successional dynamics of picocyanobacterial community in Lake Erhai (China) as inferred from 16S rRNA gene sequences. Fresen. Environ. Bull. 20:2284-2294.

Lindström ES, Bergström AK, 2005. Community composition of bacterioplankton and cell transport in lakes in two different drainage areas. Aquat. Sci. 67:210-219.

Lindstrom ES, 2000. Bacterioplankton community composition in five lakes differing in trophic status and humic content. Microbial Ecol. 40:104-113.

Liu L, Peng Y, Zheng X, Xiao L, Yang L, 2010. Vertical structure of bacterial and archaeal communities within the sediment of a eutrophic lake as revealed by culture-independent methods. J. Freshwater Ecol. 25:565-573.

Macalady JL, Mack EE, Nelson DC, Scow KM, 2000. Sediment microbial community structure and mercury methylation in mercury-polluted Clear Lake, California. Appl. Environ. Microb. 66:1479-1488.

Mccallister SL, Bauer JE, Ducklow HW, Canuel EA, 2006. Sources of estuarine dissolved and particulate organic matter: a multi-tracer approach. Org. Geochem. 37:454-468.

Meyers PA, 1994. Preservation of elemental and isotopic source identification of sedimentary organic matter. Chem. Geol. 114:289-302.

Meyers PA, Ishiwatari R, 1993. Lacustrine organic geochemistry-an overview of indicators of organic matter sources and diagenesis in lake sediments. Org. Geochem. 20:867-900.

Meyers PA, Lallier-Vergès E, 1999. Lacustrine sedimentary organic matter records of Late Quaternary paleoclimates. J. Paleolimnol. 21:345-372.

Murray AE, Hollibaugh JT, Orrego C, 1996. Phylogenetic compositions of bacterioplankton from two California estuaries compared by denaturing gradient gel electrophoresis of $16 \mathrm{~S}$ rDNA fragments. Appl. Environ. Microb. 62:2676-2680.

Muyzer G, Smalla K, 1998. Application of denaturing gradient gel electrophoresis (DGGE) and temperature gradient gel electrophoresis (TGGE) in microbial ecology. Anton. Leeuw. 73:127-141.

O'Leary MH, 1988. Carbon isotopes in photosynthesis. Bioscience:328-336.

Pan H, Wang Y, Dong Y, 1999. Factor analysis of eutrophication in Erhai Lake. J. Lake Sci. 11:184-188.

Pennanen T, 2001. Microbial communities in boreal coniferous forest humus exposed to heavy metals and changes in soil $\mathrm{pH}$ - a summary of the use of phospholipid fatty acids, Biolog and ${ }^{3} \mathrm{H}$-thymidine incorporation methods in field studies. Geoderma 100:91-126. 
Prahl FG, Ertel JR, Goni MA, Sparrow MA, Eversmeyer B, 1994. Terrestrial organic carbon contributions to sediments on the Washington margin. Geochim. Cosmochim. Ac. 58:3035-3048.

Riemann L, F Steward G, Fandino LB, Campbell L, Landry MR, Azam F, 1999. Bacterial community composition during two consecutive NE Monsoon periods in the Arabian Sea studied by denaturing gradient gel electrophoresis (DGGE) of rRNA genes. Deep-Sea Res. PT. II 46:1791-1811.

Rooney-Varga JN, Giewat MW, Savin MC, Sood S, Legresley M, Martin JL, 2005. Links between phytoplankton and bacterial community dynamics in a coastal marine environment. Microbial Ecol. 49:163-175.

Saitou N, Nei M, 1987. The neighbor-joining method: a new method for reconstructing phylogenetic trees. Mol. Biol. Evol. 4:406-425.

Salles JF, De Souza FA, Van Elsas JD, 2002. Molecular method to assess the diversity of Burkholderia species in environmental samples. Appl. Environ. Microb. 68:1595-1603.

Salles JF, Van Veen JA, Van Elsas JD, 2004. Multivariate analyses of Burkholderia species in soil: effect of crop and land use history. Appl. Environ. Microb. 70:4012-4020.

Schelske CL, Hodell DA, 1995. Using carbon isotopes of bulk sedimentary organic matter to reconstruct the history of nutrient loading and eutrophication in Lake Erie. Limnol. Oceanogr. 40:918-929.

Stuiver M, 1975. Climate versus changes in ${ }^{13} \mathrm{C}$ content of the organic component of lake sediments during the Late Quarternary. Quaternary Res. 5:251-262.

Talbot MR, Johannessen T, 1992. A high resolution palaeoclimatic record for the last 27,500 years in tropical West Africa from the carbon and nitrogen isotopic composition of lacustrine organic matter. Earth Planet. Sc. Lett. 110:23-37.

Tamura K, Dudley J, Nei M, Kumar S, 2007. MEGA4: molecular evolutionary genetics analysis (MEGA) software version 4.0. Mol. Biol. Evol. 24:1596-1599.

Tareq SM, Kitagawa H, Ohta K, 2011. Lignin biomarker and isotopic records of paleovegetation and climate changes from Lake Erhai, southwest China, since $18.5 \mathrm{kaBP}$. Quatern. Int. 229:47-56.

Ter Braak CJ, Verdonschot PF, 1995. Canonical correspondence analysis and related multivariate methods in aquatic ecology. Aquat. Sci. 57:255-289.

Teske A, Durbin A, Ziervogel K, Cox C, Arnosti C, 2011. Microbial community composition and function in permanently cold seawater and sediments from an Arctic fjord of Svalbard. Appl. Environ. Microb. 77:2008-2018.

Teske A, Wawer C, Muyzer G, Ramsing NB, 1996. Distribution of sulfate-reducing bacteria in a stratified fjord (Mariager Fjord, Denmark) as evaluated by most-probable-number counts and denaturing gradient gel electrophoresis of PCRamplified ribosomal DNA fragments. Appl. Environ. Microb. 62:1405-1415.

Teske AP, 2006. Microbial communities of deep marine subsurface sediments: molecular and cultivation surveys. Geomicrobiol. J. 23:357-368.

Thompson JD, Higgins DG, Gibson TJ, 1994. CLUSTAL W: improving the sensitivity of progressive multiple sequence alignment through sequence weighting, position-specific gap penalties and weight matrix choice. Nucleic Acids Res. 22:4673-4680.
Tong Y, Lin G, Ke X, Liu F, Zhu G, Gao G, Shen J, 2005. Comparison of microbial community between two shallow freshwater lakes in middle Yangtze basin, East China. Chemosphere 60:85-92.

Torsvik V, vreås L, Thingstad TF, 2002. Prokaryotic diversitymagnitude, dynamics, and controlling factors. Science 296:1064-1066.

Tšertova N, Kisand A, Tammert H, Baty F, Kisand V, 2013. Homogeneous microbial diversity in the upper sediment layers of a shallow lake. Aquat. Microb. Ecol. 703:77-85.

Wang Z, Wang Y, Hu M, Li Y, Liu Y, Shen Y, Wang G, 2011. Succession of the phytoplankton community in response to environmental factors in north Lake Erhai during 20092010. Fresen. Environ. Bull. 20:2221-2231.

Wan, GJ, 1999. The 137Cs dating of annual layers of recent sediments: examples from Hongfeng Lake and Erhai Lake. Quaternary Sci. 1:73-80.

Widdel F, Bak F. 1992. Gram-negative mesophilic sulfate-reducing bacteria. Springer.

Wobus A, Bleul C, Maassen S, Scheerer C, Schuppler M, Jacobs E, Röske I, 2003. Microbial diversity and functional characterization of sediments from reservoirs of different trophic state. FEMS Microbiol. Ecol. 46:331-347.

Wu F, Qing H, Wan G, 2001. Regeneration of N, P and Si near the sediment/water interface of lakes from Southwestern China Plateau. Water Res. 35:1334-1337.

Wu QL, Zwart G, Wu J, Kamst-Van Agterveld MP, Liu S, Hahn MW, 2007. Submersed macrophytes play a key role in structuring bacterioplankton community composition in the large, shallow, subtropical Taihu Lake, China. Environ. Microbiol. 9:2765-2774.

Xu JY, Wan GJ, Wang CS, Huang RG, Chen JA, 1999. The vertical profiles of ${ }^{210} \mathrm{~Pb}$ and ${ }^{137} \mathrm{Cs}$ and its dating in recent sediments of Lake Erhai and Lake Lugu. J. Lake Sci. 11:110-116.

$\mathrm{Xu} \mathrm{S}$, Zheng G, 2003. Variations in radiocarbon ages of various organic fractions in core sediments from Erhai Lake, SW China. Geochem. J. 37:135-144.

Yamada T, Sekiguchi Y, Hanada S, Imachi H, Ohashi A, Harada H, Kamagata Y, 2006. Anaerolinea thermolimosa sp. nov., Levilinea saccharolytica gen. nov., sp. nov. and Leptolinea tardivitalis gen. nov., sp. nov., novel filamentous anaerobes, and description of the new classes Anaerolineae classis nov. and Caldilineae classis nov. in the bacterial phylum Chloroflexi. Int. J. Syst. Evol. Micr. 56:1331-1340.

Yang SH, Song TQ, 2006. [Problems of pollution derived from agriculture in Erhai Lake district and countermeasures].[Article in Chinese]. Res. Agric. Moderniz. 6:007.

Yannarell AC, Triplett EW, 2005. Geographic and environmental sources of variation in lake bacterial community composition. Appl. Environ. Microb. 71:227-239.

Zeng J, Yang L, Li J, Liang Y, Xiao L, Jiang L, Zhao D, 2009. Vertical distribution of bacterial community structure in the sediments of two eutrophic lakes revealed by denaturing gradient gel electrophoresis (DGGE) and multivariate analysis techniques. World J. Microb. Biot. 25:225-233.

Zhao X, Yang L, Yu Z, Peng N, Xiao L, Yin D, Qin B, 2008. Characterization of depth-related microbial communities in lake sediment by denaturing gradient gel electrophoresis of amplified 16S rRNA fragments. J. Environ. Sci. 20:224-230. 